\title{
Feeding rate and frequency on juvenile pompano growth
}

\author{
Viviana Lisboa da Cunha(1), Marcelo Roberto Pereira Shei(1), \\ Marcelo Hideo Okamoto(1), Ricardo Vieira Rodrigues ${ }^{(1)}$ and Luís André Sampaio(1)
}

\begin{abstract}
(1)Universidade Federal do Rio Grande, Instituto de Oceanografia, Laboratório de Piscicultura Estuarina e Marinha, Caixa Postal 474, CEP 96201-900 Rio Grande, RS, Brazil. E-mail: viviana_aquicultura@yahoo.com.br, marceloshei@gmail.com, mar_okamoto@yahoo.com.br, vr.ricardo@gmail.com, sampaio@mikrus.com.br
\end{abstract}

Abstract - The objective of this work was to evaluate the ideal feeding rate and frequency for juvenile pompano (Trachinotus marginatus). Two experiments were carried out in a completely randomized design, with three replicates each. In experiment I, 25 fish $(4.8 \pm 0.6 \mathrm{~g}$ and $6.48 \pm 0.01 \mathrm{~cm})$ were stocked in 15 tanks $(50 \mathrm{~L})$ during 21 days and fed 4, 8, 12, 16, and $20 \%$ body weight per day. In experiment II, 20 fish $(4.1 \pm 0.1 \mathrm{~g}$ and $6.6 \pm 0.1 \mathrm{~cm})$ were stocked in 15 tanks $(40 \mathrm{~L})$ during 28 days and fed 2, 6, 8, and 10 times a day. The tested feeding rates and frequencies did not influence survival. Final weight and length in experiment I were significantly lower in fish fed $4 \%$ body weight per day, whereas in experiment II only weight was significantly lower in fish fed 2 and 6 times a day. At the end of both experiments, apparent feed conversion showed significant difference, with the worst value observed for fish fed $20 \%$ body weight per day in experiment I and 2 times a day in experiment II. Juvenile pompano show better growth performance when fed $8 \%$ body weight per day and 8 times a day.

Index terms: Trachinotus marginatus, feed management, marine fish culture.

\section{Taxa e frequência alimentar no crescimento de juvenis de pampo}

\begin{abstract}
Resumo - O objetivo deste trabalho foi avaliar a taxa e a frequência alimentar ideal para juvenis de pampo (Trachinotus marginatus). Foram conduzidos dois experimentos, em delineamento inteiramente casualizado, com três repetições cada um. No experimento I, 25 peixes $(4,8 \pm 0,6 \mathrm{~g}$ e $6,48 \pm 0,01 \mathrm{~cm})$ foram estocados em 15 tanques ( $50 \mathrm{~L}$ ) durante 21 dias e alimentados com 4, 8, 12, 16 e $20 \%$ da biomassa total por dia. No experimento II, 20 peixes $(4,1 \pm 0,1 \mathrm{~g}$ e $6,6 \pm 0,1 \mathrm{~cm})$ foram estocados em 15 tanques $(40 \mathrm{~L})$ durante 28 dias e alimentados 2, 6, 8 e 10 vezes por dia. As taxas e as frequências alimentares testadas não influenciaram a sobrevivência. $O$ peso e o comprimento finais no experimento I foram significativamente menores nos peixes alimentados com $4 \%$ da biomassa total por dia, enquanto, no experimento II, somente o peso foi significativamente menor nos peixes alimentados 2 e 6 vezes por dia. Ao final dos dois experimentos, a conversão alimentar aparente apresentou diferença significativa, com pior valor observado nos peixes alimentados com $20 \%$ da biomassa total por dia, no experimento I, e 2 vezes por dia no experimento II. Juvenis de pampo apresentam melhor desempenho de crescimento quando alimentados com $8 \%$ da biomassa total por dia e oito vezes por dia.
\end{abstract}

Termos para indexação: Trachinotus marginatus, manejo alimentar, piscicultura marinha.

\section{Introduction}

The selection of new fish species with good potential for aquaculture is crucial for the development of this growing industry (Tutman et al., 2004). Carangidae fish support a diverse array of economically important fisheries in tropical and subtropical waters worldwide (Crabtree et al., 2002), and species of Trachinotus have already been considered suitable candidates for mariculture due to their easy adaptation to culture systems, acceptance of formulated feeds, and fast growth rates (Crabtree et al., 2002; Tutman et al., 2004; Weirich et al., 2006).
One of the species that stands out is the pompano (Trachinotus marginatus), an euryhaline fish (Sampaio et al., 2003) that inhabits shallow coastal waters from Rio de Janeiro, Brazil, to Uruguay (Menezes \& Figueiredo, 1980). Several researches have been conducted to assess the culture of this species (Sampaio et al., 2003; Chaves et al., 2006; Cunha et al., 2009; Okamoto et al., 2009; Kütter et al., 2012, 2013).

However, in order to evaluate and develop ideal conditions for the production of new aquaculture species, among others requirements, it is necessary to establish an appropriate feed protocol. The determination of feed protocol is important to improve 
environmental safety and economic return (Cho et al., 2007; Kim et al., 2007), and one of the ways to achieve this goal is by determining fish feeding rate and frequency.

Studies have shown that a suitable feeding rate and frequency improve growth and feed conversion (Wang et al., 1998; Van Ham et al., 2003; Cho et al., 2007), reduce variation in fish size within groups (Jobling, 1994), and minimize feed wastage and water pollution (Puvanendran et al., 2003).

The objective of this work was to evaluate the ideal feeding rate and frequency for juvenile pompano.

\section{Materials and Methods}

Juvenile pompano were captured in shallow coastal waters at Cassino beach, RS, in the South region of Brazil $\left(32^{\circ} 12^{\prime} \mathrm{S}, 52^{\circ} 10^{\prime} \mathrm{W}\right)$, using a beach seine net ( $2.5 \times 1.5 \mathrm{~m}, 5.0 \mathrm{~mm}$ mesh opening), and were taken to the Laboratório de Piscicultura Estuarina e Marinha, at the Universidade Federal do Rio Grande, in March 2007. Fish were treated with a prophylactic formalin bath $(100 \mathrm{ppm})$ for 1 hour, in order to remove external parasites, and were acclimatized in a $1.000 \mathrm{~L}$ tank for one month before the beginning of the experiments. Fish were fed until visual satiation three times a day with a NRD commercial diet (INVE Aquaculture, Inc., Salt Lake City, UT, USA) (59\% protein, 16\% lipid, $1 \mathrm{~mm}$ diameter). The tank was siphoned to remove uneaten feed and feces, and at least $90 \%$ of the water was exchanged every day.

The following parameters were measured daily: water temperature and dissolved oxygen, using an oxygen meter YSI 55, (YSI Incorporated, Yellow Springs, OH, USA); salinity, with a hand-held refractometer S/Mill-E, (Atago Co., Tokyo, Japan); $\mathrm{pH}$, using a $\mathrm{pH}$ meter Q400A, (Quimis, Diadema, SP, Brazil); and total ammonia nitrogen (TA-N), using the method described by the American Public Health Association (2005). With the exception of temperature, which averaged $24.2 \pm 0.2^{\circ} \mathrm{C}$ and $25.0 \pm 0.1^{\circ} \mathrm{C}$ for experiment $\mathrm{I}$ and II, respectively, the other parameters did not differ among treatments and experiments: dissolved oxygen (5.38 $\left.\pm 0.1 \mathrm{mg} \mathrm{L}^{-1} \mathrm{O}_{2}\right)$, salinity $\left(35 \pm 0 \mathrm{~g} \mathrm{~L}^{-1}\right), \mathrm{pH}(7.77 \pm 0.3)$, and TA-N $\left(1.05 \pm 0 \mathrm{mg} \mathrm{L}^{-1} \mathrm{TA}-\mathrm{N}\right)$. Both experiments were carried out simultaneously in a completely randomized design.
In experiment I, five feeding levels were evaluated, all with three replicates: $4,8,12,16$, and $20 \%$ body weight per day. The experiment lasted for 21 days, during which 25 fish $(4.8 \pm 0.6 \mathrm{~g}$ and $6.48 \pm 0.01 \mathrm{~cm})$ were stocked in 15 cylindrical tanks (50 L). To prevent escape, all tanks were covered with mesh. Fish were fed six times a day (at 2, 6, 10, 14, 18, and 22h).

In experiment II, four feeding frequencies were tested during 28 days: 2 ( 0 and $12 \mathrm{~h}), 6(0,4,8,12$, 16 , and 20h), $8(0,3,6,9,12,15,18$, and $21 \mathrm{~h})$, and 10 (0h, 2h30, 5h, 7h30, 10h, 12h30, 15h, 17h30, 20h, and 22h30) times a day, with three replicates each. Twenty fish $(4.1 \pm 0.1 \mathrm{~g}$ and $6.6 \pm 0.1 \mathrm{~cm})$ were randomly stocked in 15 cylindrical-conical tanks (40 L). For all treatments, fish were fed $12 \%$ body weight per day.

At the beginning of the experiment and every week thereafter, 15 fish from each tank were sampled, anesthetized with benzocaine $(50 \mathrm{ppm})$ (Okamoto et al., 2009), and individually measured and weighed. Fish were returned to their respective tanks after these procedures and no mortality was observed following fish manipulation. Fish were not fed for 24 hours before measurements were taken. After this, biomass was calculated and the amount of feed offered was adjusted.

At the end of the experimental period, the following zootechnical parameters were calculated: specific growth rate, $\mathrm{G}=100 \times\left[\left(\ln \mathrm{W}_{\mathrm{f}}-\ln \mathrm{W}_{\mathrm{i}}\right) /\right.$ day $]$, in which $\mathrm{W}_{\mathrm{i}}$ and $\mathrm{W}_{\mathrm{f}}$ are the initial and final mean weight, respectively; apparent feed conversion, AFC $=$ dry feed offered (g) / biomass gain (g); weight coefficient of variation, $\mathrm{CV}=($ standard deviation $/$ mean $) \times 100$; survival, $\mathrm{S}=\left[\left(\mathrm{N}_{\mathrm{i}}-\mathrm{N}_{\mathrm{f}}\right) / \mathrm{N}_{\mathrm{i}}\right] \times 100$, in which $\mathrm{N}_{\mathrm{i}}$ is the initial number of fish and $\mathrm{N}_{\mathrm{f}}$ is the final number of fish; and condition factor, $\mathrm{CF}=\mathrm{BW} / \mathrm{L}^{3}$, in which $\mathrm{BW}$ is the body weight $(\mathrm{mg})$ and $\mathrm{L}$ is the length $(\mathrm{cm})$.

The water and zootechnical parameters of both experiments were analyzed by one-way analysis of variance followed by Tukey's test, at $5 \%$ probability. All statistical procedures were performed with the aid of the Statistica 7.0 software (StatSoft, Inc., Tulsa, OK, USA).

\section{Results and Discussion}

The feeding rates selected did not affect survival (Table 1). Final weight and length were significantly lower for fish fed $4 \%$ body weight per day than 8,12 , 16 , and $20 \%$ body weight per day, and the maximum 
mean weight was observed for fish fed $8 \%$ body weight per day. Although apparent feed conversion (AFC) showed significant differences between treatments, with better results when feeding rate was decreased (Figure 1), there was no effect on specific growth rate (SGR) and condition factor, which were similar among feeding rates.

Optimum feeding rate is an important factor for promoting better growth and developing an appropriate feeding program (Mihelakakis et al., 2002; Cho et al., 2007). In the present study, the optimum feeding rate for juvenile pompano was $8 \%$ body weight per day, since growth was lower in fish fed with $4 \%$ body weight per day, and feeding rate above $8 \%$ body weight per day did not improve growth. The optimal feeding

Table 1. Performance of juvenile pompano (Trachinotus marginatus) fed with five different feeding rates during 21 days $^{(1)}$.

\begin{tabular}{lccccc}
\hline Parameter & \multicolumn{5}{c}{ Feeding rate (\% body weight per day) } \\
\cline { 2 - 6 } & 4 & 8 & 12 & 16 & 20 \\
\hline Survival (\%) & $100 \pm 0.0$ & $98.7 \pm 1.3$ & $97.3 \pm 2.7$ & $100 \pm 0.0$ & $100 \pm 0.0$ \\
Final weight (g) & $8.36 \pm 0.2 \mathrm{~b}$ & $9.68 \pm 0.2 \mathrm{a}$ & $9.64 \pm 0.2 \mathrm{a}$ & $9.56 \pm 0.2 \mathrm{a}$ & $9.61 \pm 0.2 \mathrm{a}$ \\
CV weight & $19.8 \pm 3.4$ & $18.6 \pm 5.0$ & $17.3 \pm 4.1$ & $18.1 \pm 4.4$ & $18.0 \pm 2.8$ \\
Final length (cm) & $7.87 \pm 0.1 \mathrm{~b}$ & $8.33 \pm 0.1 \mathrm{a}$ & $8.28 \pm 0.1 \mathrm{a}$ & $8.25 \pm 0.1 \mathrm{a}$ & $8.29 \pm 0.1 \mathrm{a}$ \\
AFC & $1.54 \pm 0.1 \mathrm{~d}$ & $2.52 \pm 0.1 \mathrm{~cd}$ & $3.56 \pm 0.2 \mathrm{c}$ & $4.85 \pm 0.2 \mathrm{~b}$ & $5.98 \pm 0.3 \mathrm{a}$ \\
SGR (\%) & $2.63 \pm 0.2$ & $3.13 \pm 0.2$ & $3.31 \pm 0.2$ & $3.37 \pm 0.1$ & $3.28 \pm 0.2$ \\
CF & $1.70 \pm 0.0$ & $1.66 \pm 0.0$ & $1.68 \pm 0.0$ & $1.69 \pm 0.0$ & $1.67 \pm 0.0$ \\
\hline
\end{tabular}

${ }^{(1)} \mathrm{CV}$, coefficient of variation; AFC, apparent feed conversion; SGR, specific growth rate; $\mathrm{CF}$, condition factor. Mean $\pm \mathrm{SE}$ from three replicates from each treatment. Means followed by different letters, in the lines, differ by Tukey's test, at $5 \%$ probability.

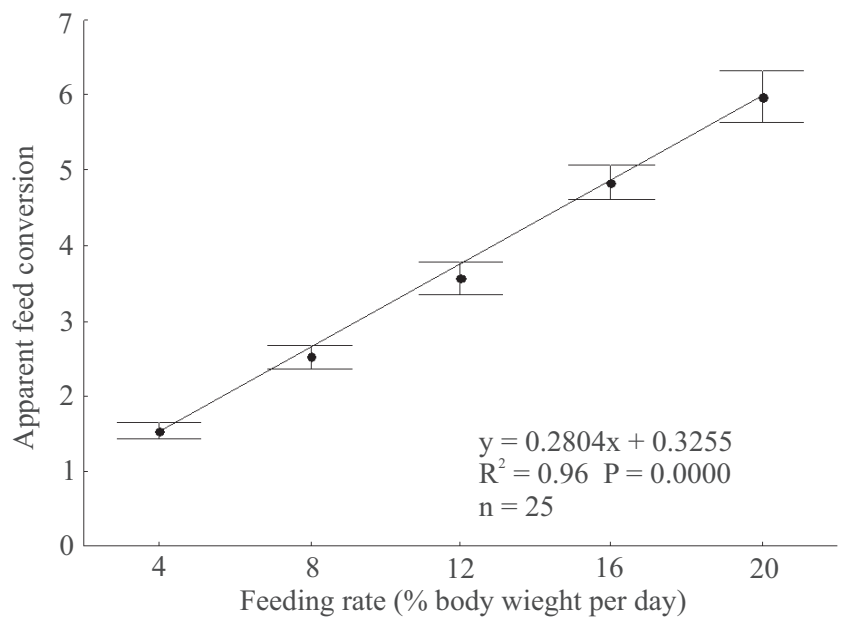

Figure 1. Apparent feed conversion of juvenile pompano (Trachinotus marginatus) as a function of feeding rate. rate found for juvenile pompano $(8 \%$ body weight per day) was high when compared to those reported for others subtropical species, such as Sparus aurata (Mihelakakis et al., 2002), Paralichthys olivaceus (Kim et al., 2007), and Limanda ferruginea (Puvanendran et al., 2003), of 2.3, 2.6, and 3.0\% body weight per day, respectively. The feeding rate of juvenile pompano seems to be closer to values found for tropical fish, including Clarias gariepinus ( $8 \%$ body weight per day) (Marimuthu et al., 2011) and Colossoma macropomum (10\% body weight per day) (Silva et al., 2007), which is probably due to the high metabolism of T. marginatus (Cunha et al., 2009).

The efficiency in converting feed into increased body mass is evaluated by AFC measurements. Increase in feeding rate affected AFC of pompano, and the best results were observed at 4 and $8 \%$ body weight per day, whereas fish fed 12,16 , and $20 \%$ body weight per day showed worse AFC. The best AFC at $4 \%$ body weight per day may have been a consequence of restricted feeding, when fish tend to optimize digestion in order to use nutrients more efficiently, improving feed efficiency (Mihelakakis et al., 2002; Kim et al., 2007). However, the increase of feeding rate did not improve SGR, which was statistically similar for all treatments. An opposite result was obtained by Sun et al. (2006), for juvenile cobia (Rachycentron canadum), and Silva et al. (2007), for juvenile tambaqui (C. macropomum), who found that an increased feeding rate increased SGR. In general, the maximum SGR and maximum feeding efficiency do not occur at the same feeding rate (Puvanendran et al., 2003). Furthermore, better growth following high AFC is an indicator of overfeeding, which results in higher production costs, water pollution, and feed wastage, and, therefore, should be avoided (Mihelakakis et al., 2002; Cho et al., 2007; Kim et al., 2007).

According to Puvanendran et al. (2003), the establishment of hierarchy in rearing tanks is common and can cause variability in fish size. Although this experiment was not designed to evaluate behavior, it was observed that pompano fed the lowest feeding rate showed aggressive behavior; however, the coefficient of variation of body weight was similar for all treatments.

Therefore, fish size, physiological state, circadian cycle, feed composition, and rearing practices also need to be taken into account because they play an 
important role on the determination of the optimum feeding rate (Jobling, 1994; Heilman \& Spieler, 1999; Puvanendran et al., 2003; Wang et al., 2007).

The tested feeding frequency did not affect survival (Table 2). Final weight was significantly higher for fish fed 10 times a day when compared to fish fed 6 and 2 times a day. However, fish fed 8 times a day did not show differences among all treatments. Moreover, no significant differences for length among feeding frequencies were detected. Pompano fed 10 and 8 times a day had higher SGR than that those fed 2 and 6 times a day. AFC was significantly higher for pompano fed 2 times a day than for those fed 10 and 8 times a day, but did not differ significantly between fish fed 2 and 6 times a day. No significant differences were observed regarding the condition factor among treatments.

Feeding frequency has a strong influence on fish growth performance and should provide the quantities of food to support good growth (Lee et al., 2000; Wang et al., 1998). The effect of feeding frequency on survival appears to be species-specific, since, as observed in the present study and for Sebastes schlegeli (Lee et al., 2000), the survival rate was not affected by feeding frequency. However, for juvenile Pagellus erythrinus, survival decreases when feeding frequency is decreased from 4 to 1 times a day (Mihelakakis et al., 2001).

Studies on feeding frequency have shown that weight gain increases when the feeding frequency is increased up to a certain limit, and that a frequency increase above this limit would result in unnecessary costs (Mihelakakis et al., 2001; Wang et al., 2007).

Table 2. Performance of juvenile pompano (Trachinotus marginatus) fed with four different feeding frequencies during 28 days ${ }^{(1)}$.

\begin{tabular}{lcccc}
\hline Parameter & \multicolumn{4}{c}{ Feeding frequency (times a day) } \\
\cline { 2 - 5 } & 2 & 6 & 8 & 10 \\
\hline Survival (\%) & $96.7 \pm 1.7$ & $100 \pm 10.0$ & $96.7 \pm 1.7$ & $96.7 \pm 1.7$ \\
Final weight (g) & $8.58 \pm 0.3 \mathrm{~b}$ & $8.78 \pm 0.2 \mathrm{~b}$ & $9.28 \pm 0.4 \mathrm{ab}$ & $9.79 \pm 0.3 \mathrm{a}$ \\
CV weight & $23.9 \pm 3.3$ & $20.9 \pm 3.5$ & $21.1 \pm 2.6$ & $24.5 \pm 1.2$ \\
Final length (cm) & $7.37 \pm 0.1$ & $7.76 \pm 0.1$ & $7.86 \pm 0.1$ & $8.02 \pm 0.1$ \\
AFC & $4.36 \pm 0.1 \mathrm{a}$ & $4.20 \pm 0.2 \mathrm{ab}$ & $3.61 \pm 0.3 \mathrm{~b}$ & $3.50 \pm 0.1 \mathrm{~b}$ \\
SGR (\%) & $2.61 \pm 0.1 \mathrm{~b}$ & $2.61 \pm 0.1 \mathrm{~b}$ & $3.19 \pm 0.1 \mathrm{a}$ & $3.29 \pm 0.1 \mathrm{a}$ \\
CF & $1.86 \pm 0.1$ & $1.87 \pm 0.1$ & $1.89 \pm 0.1$ & $1.90 \pm 0.1$ \\
\hline
\end{tabular}

${ }^{(1)} \mathrm{CV}$, coefficient of variation; AFC, apparent feed conversion; SGR, specific growth rate; $\mathrm{CF}$, condition factor. Mean $\pm \mathrm{SE}$ from three replicates from each treatment. Means followed by different letters, in the lines, differ by Tukey's test, at $5 \%$ probability.
For juvenile pompano, this limit corresponds to 8 times a day, since increasing the frequency to 10 times a day did not improve growth.

Wang et al. (1998) reported decreasing weight coefficient of variation for hybrid sunfish (female green sunfish Lepomis cyanellus $\mathrm{x}$ male bluegill L. macrochirus) at an increasing feeding frequency, suggesting a more uniform growth at higher feeding frequencies. However, this was not observed for juvenile pompano, which showed no significant difference as to the coefficient of variation in weight among treatments.

Riche et al. (2004) found that feeding frequency is strongly influenced by time of gastric evacuation, which is useful for assessing appetite return and, therefore, can be used as a tool to estimate proper feeding frequency (Lee et al., 2000). Cunha et al. (2009) suggested that the process of digestion and assimilation of food by juvenile pompano lasts for 2.5 hours, corresponding exactly to 8 times a day as observed in the present study. According to these results, it seems appropriated to feed juvenile pompano 8 times a day.

\section{Conclusions}

1. Juvenile pompano show better growth performance when fed at a feeding rate of $8 \%$ body weight per day.

2 . The best growth performance of juvenile pompano is achieved with fish fed eight times a day.

\section{Acknowledgements}

To Conselho Nacional de Desenvolvimento Científico e Tecnológico (CNPq) and to Coordenação de Aperfeiçoamento de Pessoal de Nível Superior (Capes), for financial support.

\section{References}

AMERICAN PUBLIC HEALTH ASSOCIATION. Standard methods for the examination of water and wastewater. Washington: APHA, 2005. 1193p.

CHAVES, I.S.; LUVIZZOTTO-SANTOS, R.; SAMPAIO, L.A.N.; BIANCHINI, A.; MARTÍNEZ, P.E. Immune adaptive response induced by Bicotylophora trachinoti (Monogenea: Diclidophoridae) infestation in pompano Trachinotus marginatus (Perciformes: Carangidae). Fish and Shellfish Immunology, v.21, p.242-250, 2006. DOI: 10.1016/j.fsi.2005.11.011.

CHO, S.H.; LEE, S.-M.; PARK, B.H.; JI, S.C.; CHOI, C.Y.; LEE, J.H. Effect of daily feeding ratio on growth and body composition of subadult olive flounder, Paralichthys olivaceus, fed an extruded 
diet during the summer season. Journal of the World Aquaculture Society, v.38, p.68-73, 2007. DOI: 10.1111/j.1749-7345.2006.000 74.x.

CRABTREE, R.E.; HOOD, P.B.; SNODGRASS, D. Age, growth and reproduction of permit (Trachinotus falcatus) in Florida waters. Fishery Bulletin, v.100, p.26-34, 2002.

CUNHA, V.L.; RODRIGUES, R.V.; OKAMOTO, M.H.; SAMPAIO, L.A. Consumo de oxigênio pós-prandial de juvenis do pampo Trachinotus marginatus. Ciência Rural, v.39, p.1257-1259, 2009. DOI: 10.1590/S0103-84782009005000038.

HEILMAN, M.J.; SPIELER, R.E. The daily feeding rhythm to demand feeders and the effects of timed meal-feeding on the growth of juvenile Florida pompano, Trachinotus carolinus. Aquaculture, v.180, p.53-64, 1999. DOI: 10.1016/S0044-8486(99)00140-4.

JOBLING, M. Fish bioenergetics. London: Chapman and Hall, 1994. 309p.

KIM, K.-D.; KANG, Y.J.; KIM, K-W. Effects of feeding rate on growth and body composition of juvenile flounder, Paralichthys olivaceus. Journal of the World Aquaculture Society, v.38, p.169-173, 2007. DOI: 10.1111/j.1749-7345.2006.00086.x.

KÜTTER, M.T.; MONSERRAT, J.M.; PRIMEL, E.G.; CALDAS, S.S.; TESSER, M.B. Effects of dietary $\alpha$-lipoic acid on growth, body composition and antioxidant status in the Plata pompano Trachinotus marginatus (Pisces, Carangidae). Aquaculture, v.368-369, p.29-35, 2012. DOI: 10.1016/j.aquaculture.2012.09.010.

KÜTTER, M.T.; MONSERRAT, J.M.; SANTOS, R.A.; TESSER, M.B. Dose-response effects of the antioxidant $\alpha$-lipoic acid in the liver and brain of pompano Trachinotus marginatus (Pisces, Carangidae). Journal of Applied Ichthyology, v.2013, p.1-6, 2013. DOI: 10.1111/jai.12137.

LEE, S.-M.; CHO, S.H.; KIM, D.-J. Effects of feeding frequency and dietary energy level on growth and body composition of juvenile flounder, Paralichthys olivaceus (Temminck \& Schlegel). Aquaculture Research, v.31, p.917-921, 2000. DOI: 10.1046/j.13 65-2109.2000.00505.x.

MARIMUTHU, K.; UMAH, R.; MURALIKRISHNAN, S.; XAVIER, R.; KATHIRESAN, S. Effect of different feed application rate on growth, survival and cannibalism of African catfish, Clarias gariepinus fingerlings. Emirates Journal of Food and Agriculture, v.23, p.330-337, 2011.

MENEZES, N.A.; FIGUEIREDO, J.L. Manual de peixes marinhos do Sudeste do Brasil. São Paulo: USP, 1980. 96p.

MIHELAKAKIS, A.; TSOLKAS, C.; YOSHIMATSU, T. Optimization of feeding rate for hatchery-produced juvenile gilthead sea bream Sparus aurata. Journal of the World Aquaculture Society, v.33, p.169-175, 2002. DOI: 10.1111/ j.1749-7345.2002.tb00491.x.

MIHELAKAKIS, A.; YOSHIMATSU, T.; TSOLKAS, C. Effect of feeding frequency on growth, feed efficiency, and body composition in young common pandora. Aquaculture International, v.9, p.197-204, 2001. DOI: 10.1023/A:1014203618871.
OKAMOTO, M.H.; TESSER, M.B.; LOUZADA, L.R.; SANTOS, R.A. dos; SAMPAIO, L.A. Benzocaína e eugenol como anestésicos para juvenis do pampo Trachinotus marginatus. Ciência Rural, v.39, p.866-870, 2009. DOI: 10.1590/S0103-84782008005000100.

PUVANENDRAN, V.; BOYCE, D.L.; BROW, J.A. Food ratio requirements of $0^{+}$yellowtail flounder Limanda ferruginea (Storer) juveniles. Aquaculture, v.220, p.459-475, 2003. DOI: 10.1016/ S0044-8486(02)00620-8.

RICHE, M.; HALEY, D.I.; OETKER, M.; GARBRECHT, S.; GARLING, D.L. Effect of feeding frequency on gastric evacuation and the return of appetite in tilapia Oreochromis niloticus (L.). Aquaculture, v.234, p.675-673, 2004. DOI: 10.1016/j. aquaculture.2003.12.012.

SAMPAIO, L.A.; TESSER, M.B.; BURKERT, D. Tolerância de juvenis do pampo Trachinotus marginatus (Teleostei, Carangidae) ao choque agudo de salinidade em laboratório. Ciência Rural, v.33, p.757-761, 2003. DOI: 10.1590/S0103-84782003000400027.

SILVA, C.R.; GOMES, L.C.; BRANDÃO, F.R. Effect of feeding rate and frequency on tambaqui (Colossoma macropomum) growth, production and feeding costs during the first growth phase in cages. Aquaculture, v.264, p.135-139, 2007. DOI: 10.1016/j. aquaculture.2006.12.007.

SUN, L.; CHEN, H.; HUANG, L.; WANG, Z. Growth, faecal production, nitrogenous excretion and energy budget of juvenile cobia (Rachycentron canadum) relative to feed type and ration level. Aquaculture, v.259, p.211-221, 2006. DOI: 10.1016/j. aquaculture.2006.05.024.

TUTMAN, P.; GLAVIC, N.; KOZUL, V.; SKARAMUCA, B.; GLAMUZINA, B. Preliminary information on feeding and growth of pompano, Trachinotus ovatus (Linnaeus 1758) (Pisces; Carangidae) in captivity. Aquaculture International, v.12, p.387-393, 2004. DOI: 10.1023/B:AQUI.0000042135.88381.f4.

VAN HAM, E.H.; BERNTSSEN, M.H.G.; IMSLAND, A.K.; PAPOURA, A.C.; BONGA, S.E.W.; STEFANSSON, S.O. The influence of temperature and ration on growth, feed conversion, body composition and nutrient retention of juvenile turbot (Scophthalmus maximus). Aquaculture, v.217, p.547-558, 2003. DOI: 10.1016/S0044-8486(02)00411-8.

WANG, N.; HAYWARD, R.S.; NOLTIE, D.B. Effect of feeding frequency on food consumption, growth, size variation, and feeding pattern of age-0 hybrid sunfish. Aquaculture, v.165, p.261-267, 1998. DOI: 10.1016/S0044-8486(98)00266-X.

WANG, Y.; KONG, L.-J.; LI, K.; BUREAU, D.P. Effects of feeding frequency and ration level on growth, feed utilization and nitrogen waste output of cuneate drum (Nibea miichthioides) reared in net pens. Aquaculture, v.271, p.350-356, 2007. DOI: 10.1016/j. aquaculture.2007.03.022.

WEIRICH, C.R.; GROAT, D.R.; REIGH, R.C. Effect of feeding strategies on production characteristics and body composition of Florida pompano reared in marina recirculating systems. North American Journal of Aquaculture, v.68, p.330-338, 2006. DOI: 10.1577/A05-082.1.

Received on August 1 $1^{\text {st }}, 2011$ and accepted on July 22, 2013

Pesq. agropec. bras., Brasília, v.48, n.8, p.950-954, ago. 2013

DOI: $10.1590 / \mathrm{S} 0100-204 \mathrm{X} 2013000800020$ 